\title{
DESKRIPSI JUMLAH LEUKOSIT DAN LAJU ENDAP DARAH PADA PASIEN TUBERKULOSIS DI RUMAH SAKIT PARU DUNGUS MADIUN
}

\section{Description Of Leukosit Amount And Blood Sedimentation Rate In Tuberculosis Patients In Dungus Madiun Hospital}

\author{
1*Chalies Diah Pratiwi, ${ }^{2}$ Eka Puspitasari, ${ }^{3}$ Vivi Nurohmah \\ ${ }^{1}$ Prodi Teknologi Laboratorium Medis, STIKees Hutama Abdi Husada, Jl. Dr. Wahidin Sudiro Husada, Tulungagung \\ ${ }^{2}$ Prodi Teknologi Laboratorium Medis, STIKees Hutama Abdi Husada, Jl. Dr. Wahidin Sudiro Husada, Tulungagung \\ ${ }^{3}$ Prodi Teknologi Laboratorium Medis, STIKees Hutama Abdi Husada, Jl. Dr. Wahidin Sudiro Husada, Tulungagung
}

*e-mail :diahchalies@gmail.com

\begin{abstract}
ABSTRAK
Tuberculosis merupakan penyakit menular yang menjadi perhatian global yang disebabkan oleh infeksi bakteri Mycobacterium tuberculosis, menyerangpada paru - paru maupun organ - organ lainnya seperti hati, ginjal, tulang ataupun kulit. Bila seseorangterinfeksi tuberculosis maka tubuh akanterjadi proses inflamasi,inflamasi tersebut dapat menimbulkan manifestasi hematologi. Tujuan penelitian ini adalah untuk mengetahui gambaran jumlah leukosit danLaju Endap Darah (LED) pada pasien tuberculosis. Desain penelitian yang digunakan adalah deskriptif non analitik. Populasi dalam penelitian ini adalah semua pasien tuberculosis di Rumah Sakit Paru Dungus Madiun Tahun 2018. Dengan menggunakan teknik Quota Sampling, sampel pada penelitian ini sebanyak 30 responden. Penelitian ini dilakukan pada bulan Mei 2018. Hasil dari penelitian pada pasien tuberculosis diperoleh gambaran jumlah leukosit pada penderita TB adalah $9120 \mathrm{sel} / \mu \mathrm{L}$ darah, 11 (37\%) penderita mengalami leukositosis dan 19 (63\%) penderita memiliki jumlah leukosit yang nomal. Jumlah leukosit terendah adalah 4100 sel/ $\mu \mathrm{L}$ darah dan tertinggi $24700 \mathrm{sel} / \mu \mathrm{L}$ darah. Nilai rata-rata LED pada penderita TB adalah $71 \mathrm{~mm} / \mathrm{jam} \mathrm{I,} 29$ (96,6\%) penderita mengalami peningkatan nilai LED dan 1 (3,4\%) penderita memiliki nilai LED normal. Nilai terendah LED adalah 11 $\mathrm{mm} / \mathrm{jam}$ I dan nilai tertinggi LED adalah $106 \mathrm{~mm} / \mathrm{jam}$ I. Pencegahan infeksi tuberculosis dapat dilakukan dengan melakukan pemeriksaan diagnosa laboratorium untuk mengetahui seberapa jauh perjalanan penyakitnya dan memilih OAT yang tepat untuk pasien. Dengan pengobatan yang intensif maka akan menurunkan jumlah leukosit dan mengurangi risiko untuk TB MDR.
\end{abstract}

Kata kunci : jumlah leukosit, laju endap darah (LED), Tuberculosis

\begin{abstract}
Tuberculosis is an infectious disease of global concern caused of bacterium Mycobacterium tuberculosis. It can attack lung, liver, kidneys, bones or skin. If a person infected by tuberculosis, the body will begin the mechanism of inflammation as a form of haematological manifestation. The purpose of this study was to describe the number of leukocytes and Blood Sedimentation Rate (BSR) in tuberculosis patients. The research design used is non-analytic descriptive. The population in this study were all tuberculosis patients at the Dungus Madiun Lung Hospital in 2018Using the Quota Sampling technique, the sample in this study was 30 respondents. This research was conducted on May 2018. The results of the study on tuberculosis patients showed that the number of leukocytes in TB patients was 9120 cells/ $\mu$ L blood, 11 (37\%) patients had leukocytosis and 19 (63\%) sufferers have a nominal leukocyte count. The lowest leukocyte count was 4100 cells/ $\mu$ L of blood and the highest was 24700 cells/ $\mu$ L of blood. The average value of BSR in TB patients was $71 \mathrm{~mm} /$ hour I, 29 (96.6\%) patients experienced an increase in BSR values and 1 (3.4\%) patients had normal BSR values. The lowest value of BSR is $11 \mathrm{~mm} / \mathrm{hour}$ I and the highest value of BSR is $106 \mathrm{~mm} /$ hour I. Prevention of tuberculosis infection can be done by conducting laboratory diagnosis to find out how far the disease goes and choose the right OAT for patients. With intensive treatment, it will reduce the number of leukocytes and reduce the risk for $M D R T B$.
\end{abstract}

Keyword: leukocyte count, blood sedimentation rate (BSR), Tuberculosis 


\section{PENDAHULUAN}

Tuberkulosis paru adalah penyakit radang parenkim paru karena infeksi kuman Mycobacterium tuberculosis. Tuberkulosis paru termasuk suatu pneumonia, yaitu pneumonia yang disebabkan oleh Mycobacterium tuberculosis. Tuberkulosis paru mencakup $80 \%$ dari keseluruhan kejadian penyakit tuberkulosis, sedangkan $20 \%$ selebihnya merupakan tuberculosis ekstrapulmonar (Darmanto, 2013).

Mycobacterium tuberculosis berbentuk batang, mempunyai sifat khusus yaitu tahan terhadap pewarnaanasam, sehingga disebut sebagai Basil Tahan Asam (BTA). Penularan tuberkulosis yaitu melalui percikan dahak (droplet) dari seorang penderita kepada orang yang berada disekitarnya seperti pada saat berbicara, batuk, maupun bersin. Kuman tuberkulosis dapat menyebar dari paru-paru kebagian tubuh lainnya melalui sistem peredaran darah, sistem saluran limfa, saluran nafas atau penyebaran langsung kebagian-bagian tubuh lainnya. (Wiratma, 2016).

Berdasarkan World Health Organization of Global Tuberculosis Report Tahun 2015 dari 9,6 juta kasus-kasus TB baru pada tahun 2014, negara dengan penderita tuberkulosis terbanyak yaitu berturut-turut India 23\%, Indonesia 10\% dan China 10\% dari seluruh penderita di dunia. Di Indonesia ditemukan jumlah kasus tuberkulosis sebanyak 330.910 kasus pada tahun 2015, meningkat bila dibandingkan semua kasus tuberkulosis yang ditemukan pada tahun 2014 yang sebesar 324.539 kasus. Jumlah kasus tertinggi dilaporkan terdapat di provinsi dengan jumlah penduduk yang besar yaitu Jawa Barat, Jawa Tengah dan Jawa Timur. Kasus tuberkulosis di tiga provinsi tersebut sebesar 38\% dari jumlah seluruh kasus baru di Indonesia. Menurut jenis kelamin, jumlah kasus pada laki-laki lebih tinggi dari pada perempuan yaitu 1,5 kali dibandingkan pada perempuan (Kemenkes RI, 2016). Jumlah kasus TB baru di kabupaten Madiun pada tahun 2015 ada 924 kasus (Dinkes Jatim, 2015).

Jika seseorang terkena TB maka tubuh akan terjadi proses inflamasi, inflamasi tersebut dapat menimbulkan manifestasi hematologi (Ajayi, et al., 2013). Pada dasarnya ketika seseorang terkena infeksi maka tubuh akan merespon dengan tentaranya sel leukosit dan terjadi leokositosis yaitu jumlah leukosit yang melebihi nilai normal (Nayak, et al., 2012).

Pada umumnya setiap penderita tuberculosis akan mengalami gejala-gejala umum berupa batuk berdahak lebih dari dua minggu, batuk berdarah, lemah badan, penurunan berat badan, meningkatnya suhu tubuh, keringat dimalam hari sering terjadi. (Hasnawati, 2018). Salah satu proses diagnosis penyakit Tuberkulosis yaitu dengan pemeriksaan darah seperti laju endap darah (LED) dan hitung jumlah leukosit. Laju Endap Darah (LED) dibutuhkan karena data ini dapat dipakai sebagai indikator tingkat kestabilan biologi penderita sehingga dapat digunakan untuk menilai respon terhadap pengobatan serta tingkat penyembuhan penderita. Tuberkulosis menyebabkan bertambahnya jumlah leukosit yang berkaitan dengan fungsinya sebagai pertahanan, sehingga pengendapan darah melaju lebih cepat karena bertambah jumlah sel darah (Tahumuri et al., 2017). Penelitian sebelumnya melaporkan terjadi perubahan hasil pemeriksaan hematologi yang sangat beragam, baik leukosit, eritrosit, trombosit maupun LED (Sundari et al., 2017).

Berdasarkan penjelasan diatas peneliti tertarik untuk melakukan penelitian mengenai Deskripsi Jumlah Leukosit Dan Laju Endap Darah Pada Pasien Tuberkulosis Di Rumah Sakit Paru Dungus Madiun.

\section{METODE PENELITIAN}

Penelitian ini dilakukan padabulan Mei 2018. Desain penelitian yang digunakan adalah deskriptif non analitik. Populasi dalam penelitian ini adalah semua pasien tuberkulosisdi Rumah Sakit Paru Dungus Madiun Tahun 2018. Sampel pada penelitian ini sebanyak 30 responden yang memiliki kriteria inklusi pasien TB dengan BTA positif dan HIV negatif menggunakan teknik Quota Sampling.

\section{Pengumpulan Data}

Pemeriksaan hitung jumlah leukosit menggunakan Hematology Analyzer berdasarkan prinsip flow cytometry dimana alat akan mengukur sel darah secara otomatis berdasarkan impedansi 


\section{BJMLT}

aliran listrik terhadap sel-sel yang dilewatkan (Keohane, et al., 2016). Sedangkan pemeriksaan LED menggunakan tabung serologi, push ball, pipet Westergreen, dan rak Westergreen. Sampel yang digunakan untuk pemeriksaan adalah darah EDTA yang disampling pada penderita TB menggunakan spuid dan kapas alkohol $70 \%$.

Data penelitian yang didapatkan dari hasil pemeriksaan hitung jumlah leukosit dan Laju Endap Darah (LED) pada penderita Tuberkulosis di Rumah Sakit Paru Dungus Madiun diolah secara deskriptif.

\section{HASIL DAN PEMBAHASAN}

Hasil pemeriksaan Jumlah Leukosit dan Laju Endap Darah pada Pasien Tuberkulosis di Rumah Sakit Paru Dungus Madiun ditampilkan pada tabel berikut.

TABEL 1. Karakteristik Berdasarkan Jenis Kelamin Pasien TB

\begin{tabular}{lcc}
\hline Jenis Kelamin & Frekuensi (n) & Persentase (\%) \\
\hline Laki - laki & 20 & 67 \\
\hline Perempuan & 10 & 33 \\
\hline
\end{tabular}

Berdasarkan Tabel 1 jenis kelamin pasien TB menunjukan cenderung ditemui pada laki - laki (67\%) dibandingkan dengan perempuan (33\%). Hal ini sejalan dengan penelitian yang menyatakan berdasarkan jenis kelamin menunjukkan bahwa penyakit TB cenderung lebih banyak dijumpai pada laki-laki sebanyak 58\% dibandingkan dengan perempuan sebanyak $42 \%$. Pada umumnya faktor resiko laki-laki merokok dan mengkonsumsi minuman beralkohol yang mengakibatkan penurunan daya tahan tubuh yang berakibat rentan terkena penyakit paru ataupun terpapar kuman Mycobacterium tuberculosis (Khaironi at al, 2017).

TABEL 2. Karakteristik Berdasarkan Usia Pasien TB

\begin{tabular}{lcc}
\hline Jenis Kelamin & Frekuensi (n) & Persentase (\%) \\
\hline 15-50 Tahun & 18 & 60 \\
\hline$>50$ Tahun & 12 & 40 \\
\hline
\end{tabular}

Berdasarkan Tabel 2 Kelompok usia pada pasien TB cenderung ditemui pada usia produktif $(15-50$ tahun) yaitu sebesar $60 \% \quad(18$ responden $)$ dibandingkan dengan usia $>50$ tahun $40 \%$ (12 responden). Hal ini sejalan dengan penelitian yang menyatakan bahwa pasien tuberkulosis sering ditemui pada usia produktif.(Khaironi at al, 2017)Hal ini terjadi dikarenakan pada usia produktif seseorang cenderung memiliki mobilitas dan interaksi sosial tinggi yangmenyebabkan kelelahan dan penurunan imunitas tubuh yang bersifat rentanterinfeksi dari orang lain menjadi lebih tinggi (Sahal, 2014).

TABEL 3. Jumlah Leukosit dan LED Pasien TB

\begin{tabular}{|c|c|c|}
\hline \multirow[b]{2}{*}{ No } & \multicolumn{2}{|c|}{ Hasil Pemeriksaan } \\
\hline & Hitung Jumlah Leukosit & LED \\
\hline 1. & 11,4 & 106 \\
\hline 2. & 7,1 & 45 \\
\hline 3. & 10,1 & 106 \\
\hline 4. & 7,4 & 11 \\
\hline 5. & 9,2 & 31 \\
\hline 6. & 8,8 & 35 \\
\hline 7. & 4,6 & 98 \\
\hline 8. & 7,4 & 105 \\
\hline 9. & 10,8 & 83 \\
\hline 10. & 11,6 & 52 \\
\hline 11. & 8,2 & 66 \\
\hline 12. & 9,3 & 99 \\
\hline 13. & 5,5 & 89 \\
\hline 14. & 7,2 & 97 \\
\hline 15. & 24,7 & 22 \\
\hline 16. & 11,2 & 82 \\
\hline 17. & 11,4 & 100 \\
\hline 18. & 13,0 & 82 \\
\hline 19. & 7,0 & 50 \\
\hline 20. & 10,1 & 47 \\
\hline 21. & 12,0 & 102 \\
\hline 22. & 5,2 & 56 \\
\hline 23. & 4,1 & 67 \\
\hline 24. & 9,9 & 78 \\
\hline 25. & 9,3 & 76 \\
\hline 26. & 6,5 & 86 \\
\hline 27. & 11,2 & 82 \\
\hline 28. & 4,1 & 75 \\
\hline 29. & 8,6 & 52 \\
\hline 30. & 6,7 & 38 \\
\hline
\end{tabular}

Berdasarkan Tabel 3 dapat diketahui bahwa rata-rata jumlah leukosit pada penderita TB adalah $9120 \mathrm{sel} / \mu \mathrm{L}$ darah, 11(37\%) penderita mengalami 
leukositosis dan 19(63\%) penderita memiliki jumlah leukosit yang nomal. Jumlah leukosit terendah adalah $4100 \mathrm{sel} / \mu \mathrm{L}$ darah dan tertinggi $24700 \mathrm{sel} / \mu \mathrm{L}$ darah.

Hal ini sejalan dengan penelitian terdahulu yang menyatakan pemeriksaan jumlah leukosit secara keseluruhan pada pasien TB sebelum pengobatan yang normal sebanyak 75\% (Khaironi, et al., 2017). Penderita Tuberkulosis dengan jumlah leukosit normal memiliki imunitas yang baik ketika kuman penyebab tuberkulosis menginfeksi paru-paru maka kuman penyebab tuberkulosis akan difagositosis makrofag alveolar dan umumnya dapat dihancurkan sehingga tidak dapat terjadi pertumbuhan kuman. (Hasan, 2004).

Pada penelitian terdahulu juga menyatakan pemeriksaan jumlah leukosit secara keseluruhan pada pasien TB sebelum pengobatan diatas normal sebanyak 25\% (Khaironi at al, 2017). Peningkatan jumlah leukosit menunjukkan adanya perlawan dari tubuh untuk melawan kuman Mycobacterium tuberculosis. Neutrofil sendiri menjadi pertahanan pertama melawan infeksi pada bakteri dengan cara melisiskan dan memfagositosis bakteri (Sari, 2015). Adanya peningkatan jumlah leukosit pada pasien TB menunjukkan adanya pembentukkan leukosit yang banyak untuk melawan bakteri penyebab penyakit TB dalam proses fagositosis secara keseluruhan (Khaironi, et al., 2017).

Berdasarkan Tabel 3 dapat diketahui bahwa rata-rata LED pada penderita TB adalah $71 \mathrm{~mm} / \mathrm{jam}$ I, $29(96,6 \%)$ penderita mengalami peningkatan nilai LED dan $1(3,4 \%)$ penderita memiliki nilai LED normal. Nilai terendah LED adakah $11 \mathrm{~mm} / \mathrm{jam}$ I dan nilai tertinggi LED adalah $106 \mathrm{~mm} / \mathrm{jam}$ I. Nilai rujukan untuk pemeriksaan LED antara pria dan wanita berbeda sehingga penilaian normal atau tidak didasarkan atas nilai rujukan jenis kelamin.

Penelitian ini tidak sejalan dengan penelitian terdahulu yang menyatakan nilai rata-rata (mean) LED pada penderita TB paru di Sumatera Utara pada cara miring $45^{\circ}$ (7 menit) adalah sebesar 23,73 $\mathrm{mm} / \mathrm{jam}$ dan pada cara tegak lurus $90^{\circ}$ ( $1 \mathrm{jam}$ ) adalah sebesar 15,30 mm/jam (Wiratma, 2016). Penelitian ini lebih menekankan perbedaan metode pemeriksaan yang digunakan terhadap hasil LED.
Penelitian ini sejalan dengan penelitiandi Laboratorium Balai Besar Kesehatan Paru Masyarakat Makassar yang menyatakan terjadi peningkatan nilai LED berdasarkan derajat positif hasil BTA-nya pada 30 sampel (100\%) penderita TB paru.

LED merupakan respon terhadap trauma, inflamasi atau kehamilan yang ditandai dengan peningkatan kadar globulin dan fibrinogen, peningkatan LED terjadi pula apabila inflamasi kronik menjadi akut. Pemeriksaan LED secara rutin dapat menunjukkan perkembangan apakah penyakit diderita mengalami proses penyembuhan misalnya pada penyakit TB paru dan demam rematik. LED adalah reaksi non sfesifik dari tubuh, dikatakandemikian karena LED biasa meninggi pada penyakit-penyakit atau keadaan phatologis apa saja. LED biasanya tetap dalam batas normal pada penyakit-penyakit appendiatur infeksi setempat yang kecil, misalnya appendiatur akut dalam fase infeksi pada selaput lendir dengan sedikit reaksi radang (Hasnawati, 2018).

Peningkatan nilai LED dalam penelitian ini juga selaras dengan penelitian terdahulu yang menyatakan Peningkatan LED ditemukan hampir seluruh penderita (97\%) baik yang terinfeksi MTB galur Beijing maupun galur non Beijing. Peningkatan LED menunjukkan proses inflamasi. Tingginya LED ini menunjukkan beratnya penyakit (Sundari, 2017).

Peningkatan LED oleh kerusakan jaringan seperti tuberculosis dan infeksi kronis lainnya akan merubah konsentrasi kandungan protein plasma seperti fibrinogen dan globulin yang menyertai sebagian besar infeksi akut dan kronis cenderung akan meningkatkan pembentukan rouleaux (Kalma, et al., 2015) .

\section{KESIMPULAN}

Hasil dari penelitian pada pasien tuberkulosis diperoleh deskripsijumlah rata-rata leukosit pada penderita TB adalah $9120 \mathrm{sel} / \mu \mathrm{L}$ darah, 11 (37\%) penderita mengalami leukositosis dan 19 (63\%) penderita memiliki jumlah leukosit yang nomal. Jumlah leukosit terendah adalah $4100 \mathrm{sel} / \mu \mathrm{L}$ darah dan tertinggi $24700 \mathrm{sel} / \mu \mathrm{L}$ darah. Nilai rata-rata LED 
pada penderita TB adalah $71 \mathrm{~mm} / \mathrm{jam} \mathrm{I,} 29$ (96,6\%) penderita mengalami peningkatan nilai LED dan 1 $(3,4 \%)$ penderita memiliki nilai LED normal. Nilai terendah LED adakah $11 \mathrm{~mm} / \mathrm{jam}$ I dan nilai tertinggi LED adalah $106 \mathrm{~mm} / \mathrm{jam}$ I.Bagi peneliti selanjutnya sebaiknya dilakukan penelitian serupa dengan mencari perbedaan jumlah leukosit, jenis sel leukosit dan LED pada penderita TB sebelum dan sesudah pengobatan.

\section{DAFTAR PUSTAKA}

Ajayi, O.I., Kosamat, Y.A., Isamot, I.A., Kolawole, L. I., Dayo-Ajayi, O.M., \& Nwatu, B. 2013. Evidence of Improved Haematological Profile of Nigerian Pulmonary Tuberculosis Patients Undergoing DOTS Regimen. Annals Biomed Sci. 2(2).

Darmanto, R. 2013. Respirologi (Respiratory Medicine). Jakarta : Penerbit Buku Kedokteran EGC.

Dinkes Jatim. 2015. Profil Kesehatan Provinsi Jawa Timur. Surabaya : Dinas Kesehatan Provinsi Jawa Timur.

Hasan, H., \& Lulu, M.U.S. 2004. Buku Ajar Penyakit Paru, Edisi 1. Surabaya : Graha Masyarakat Ilmiah Kedokteran Universitas Airlangga.

Hasnawati. 2018. Pengaruh Infeksi Mycobacterium Tuberculosis Terhadap Nilai Laju Endap Darah Penderita Tuberculosis Paru Di Balai Besar Kesehatan Paru Masyarakat Makassar. Jurnal Media Analis Kesehatan. 1(1).

Kemenkes RI. 2016. Profil Kesehatan Indonesia Tahun 2015. Jakarta : Kementerian Kesehatan Republik Indonesia.

Kalma, Bakhri, S., Naim, N., Umar, B., $\&$ Hurustiaty. 2015. Plebotomi Terapan. Poltekkes Kemenkes RI.

Keohane, E. M., Smith, L. J., \& Walenga, J. M., 2016. Rodak's Hematology Clinical Principles And Applications. Amerika : Elsevier.

Khaironi, R., et al. 2017. Gambaran Jumlah Leukosit Dan Jenis Leukosit Pada Pasien Tuberkulosis Paru Sebelum Pengobatan Dengan Setelah
Pengobatan Satu Bulan Intensif Di Puskesmas Pekanbaru. Jurnal Analis Kesehatan Klinikal Sains. 5(2).

Nayak, R.et al. 2012. Essentials in Hematology and Clinical Pathology. New Delhi : Jaypee Brothers Medical Publishers.

Sahal, Y. P. et al. 2014. Hubungan Jumlah Sel Limposit dengan Usia dan Status Nutrisi pada Penderita Tuberkulosis. Global Medical and Health Communication. 2(2):73-78

Sari, P. 2015. Hubungan Pajanan Fomaldehida Dengan Jumlah Leukosit, Hitung Jenis Dan Morfologinya Pada Pekerja Laki - Laki Bagian Dipping Dan Weaving Industri Kain Ban. Skripsi. Universitas Indonesia, Jakarta.

Sundari, R., et al. 2017. Perbedaan Parameter Hematologi pada Penderita Tuberkulosis Paru Terinfeksi Mycobacterium Tuberculosis Galur Beijing dengan Galur NonBeijing. Journal MKB. 49(1):35-42.

Tahumurin, A. 2017. Gambaran Laju Endap Darah Dan C-Reactive Protein Pada Pasien Tuberkulosis Paru Di Manado 2016. Jurnal Kedokteran Klinik (JKK). 1(3).

Wiratma, D, Y,. \& Ariustika, S. 2016. Pengaruh Perbedaan Metode Pemeriksaan Laju Endap Darah (Led) Terhadap Nilai Led Pasien Tersangka Penderita Tuberkulosis Paru Di Upt.Kesehatan Paru Masyarakat Dinas Kesehatan Provinsi Sumatera Utara Medan Tahun 2015. Jurnal Analis Laboratorium Medik. 1(1). 